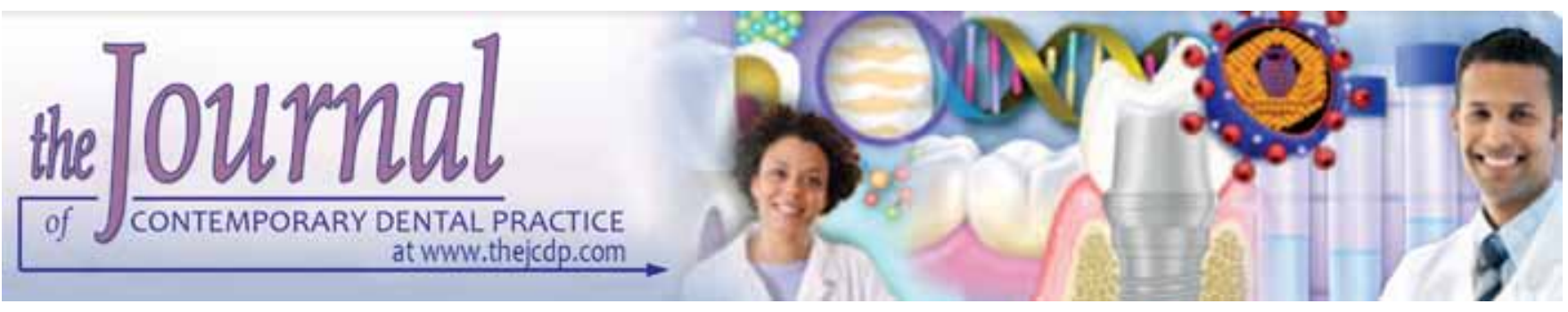

\title{
Influence of Disinfection with Peracetic Acid and Hypochlorite in Dimensional Alterations of Casts obtained from Addition Silicone and Polyether Impressions
}

Daher Antonio Queiroz, Marcelo Massaroni Peçanha, Ana Christina Claro Neves, Fausto Frizzera, Mateus Rodrigues Tonetto, Laís Regiane Silva-Concílio

\begin{abstract}
Dental impressions disinfection is important to reduce the risk of cross contamination but this process may produce dimensional distortions. Peracetic acid is a disinfectant agent with several favorable characteristics yet underutilized in Dentistry. The aim of this paper is to compare the dimensional stability of casts obtained from addition silicone and polyether impressions that were immersed for 10 minutes in a solution of $0.2 \%$ peracetic acid or $1 \%$ sodium hypochlorite. Sixty samples in type IV gypsum were produced after a master cast that simulated a full crown preparation of a maxillary premolar. Samples were divided in 6 groups $(n=10)$ according to the impression material and disinfection agent: Group AC - addition silicone control (without disinfectant); Group APA addition silicone $+0.2 \%$ peracetic acid; Group $\mathrm{AH}$ - addition silicone $+1 \%$ sodium hypochlorite; Group PC - polyether control (without disinfectant); Group PPA - polyether $+0.2 \%$ peracetic acid; Group $\mathrm{PH}-$ polyether $+1 \%$ sodium hypochlorite. Cast height, base and top diameter were measured and a mean value was obtained for each sample and group all data was statistically analyzed (ANOVA, $p<0.05$ ). There was not a significant statistical difference between addition silicone and polyether impressions regardless of the disinfectant materials. It can be concluded that disinfection with the proposed agents did not produce significant alterations of the impressions and the peracetic acid could be considered a reliable material to disinfect dental molds.
\end{abstract}

Keywords: Dimensional stability, Impression materials, Peracetic acid.

How to cite this article: Queiroz DA, Peçanha MM, Neves ACC, Frizzera F, Tonetto MR, Silva-Concílio LR. Influence of Disinfection with Peracetic Acid and Hypochlorite in Dimensional Alterations of Casts obtained from Addition Silicone and Polyether Impressions. J Contemp Dent Pract 2013;14(6):1100-1105.

Source of support: Nil

Conflict of interest: None declared

\section{INTRODUCTION}

Dental impression is a major step during the fabrication of prosthetics. Several materials and techniques may be chosen but there will be contamination since microorganisms are present in the oral cavity. Therefore, there is a high risk of cross infection between dental staff, technicians and patients. ${ }^{1-5}$

In order to reduce contamination, several disinfection and sterilization solutions and techniques has been recommended. ${ }^{2,4}$ Each impression material interacts differently with the disinfection agents. The appropriate solution and method of disinfection have to be selected carefully since they could interfere with the stability and accuracy of the dental casts. ${ }^{1,6,7}$

Usually the major groups of impression materials utilized in dental practice are the irreversible hydrocolloids and elastomers. Polyether and addition silicones are elastomeric materials that present excellent dimensional stability, high tear resistance and a reasonable time to produce the cast. ${ }^{8,9}$ In some cases, addition silicones impressions may be more useful as there is not a necessity to produce individual trays and more than one cast can be produced from the same impression. ${ }^{8}$

To disinfect or sterilize impression materials, solutions containing sodium hypochlorite, glutaraldehyde, ${ }^{1,10,11}$ ultraviolet radiation, ${ }^{12,13}$ autoclave sterilization and microwave disinfection ${ }^{14}$ have been proposed in the Literature. Among all the techniques and materials there is also questions regarding the ideal disinfection solution or method. ${ }^{6,15}$

Peracetic acid is utilized in several healthcare areas as an effective high level disinfectant. ${ }^{16,17}$ This material is biocompatible, biodegradable, presents a fast action even in low concentrations, acts in the presence of organic matters, may sterilize contaminated materials in short periods and has a low corrosive potential reducing the risk of equipment damage. ${ }^{18-20}$ Sodium hypochlorite has a verified disinfection 
property, but it is related to the solution concentration and storage conditions, also the presence of organic matter may reduce its action. ${ }^{11,21}$

Therefore, the aim of this paper is to compare the dimensional alterations of casts obtained from addition silicone and polyether impressions that were disinfected with $1 \%$ sodium hypochlorite or $0.2 \%$ peracetic acid. Tested hypothesis was that $0.2 \%$ peracetic acid as a disinfectant agent would not promote a significant dimensional alteration.

\section{MATERIALS AND METHODS}

Sixty impressions were made of a master cast that simulates a superior premolar with a full-crown preparation. Impressions were then disinfected with different solutions and sixty casts in type IV gypsum were produced. Utilized materials are described in Table 1.

\begin{tabular}{|c|c|c|}
\hline Product & Classification & Manufacturer \\
\hline $\begin{array}{l}\text { IMPREGUM TM } \\
\text { Soft }\end{array}$ & $\begin{array}{l}\text { Polyether } \\
\text { impression material }\end{array}$ & $\begin{array}{l}\text { IMPREGUM TM } \\
\text { Soft, 3M ESPE, St. } \\
\text { Paul, Minnesota, } \\
\text { USA }\end{array}$ \\
\hline AQUASIL & $\begin{array}{l}\text { Polyvinyl siloxane } \\
\text { impression material }\end{array}$ & $\begin{array}{l}\text { Dentsply, São } \\
\text { Paulo, Brazil }\end{array}$ \\
\hline Peracetic acid $0.2 \%$ & Disinfection agent & $\begin{array}{l}\text { STERILIFE }^{\circledR} \\
\text { Lifemed } \\
\text { ProdutosMédicos } \\
\text { Comércio Ltda, São } \\
\text { Paulo SP, Brazil }\end{array}$ \\
\hline $\begin{array}{l}\text { Sodium } \\
\text { hypochlorite } 1 \%\end{array}$ & Disinfection agent & $\begin{array}{l}\text { LM Farma, São } \\
\text { Jose' dos Campos, } \\
\text { Brazil }\end{array}$ \\
\hline Vel-Mix & $\begin{array}{l}\text { Dental stone } \\
\text { type IV }\end{array}$ & Kerr, Orange, USA \\
\hline
\end{tabular}

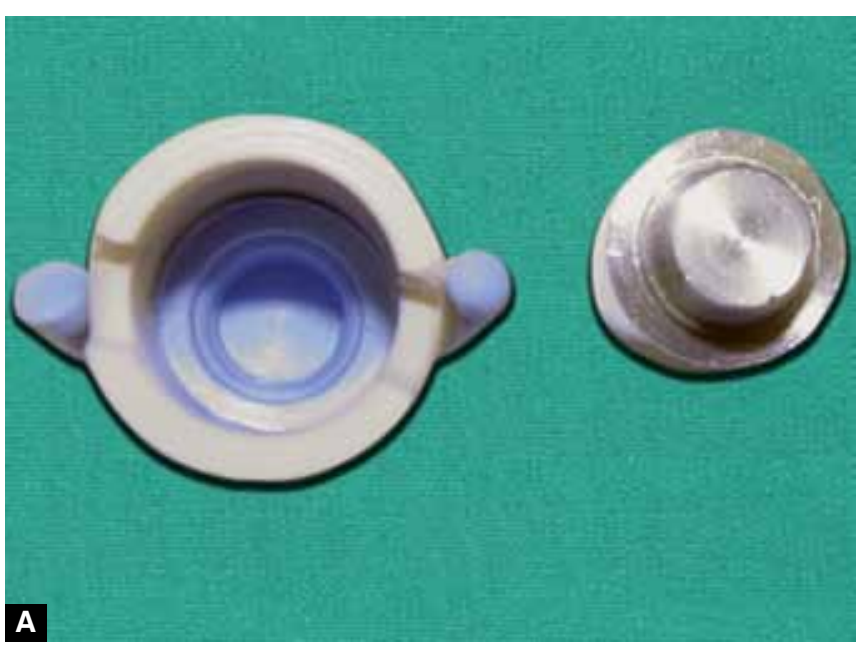

\section{MASTER CASTS}

Two metal casts in $\mathrm{CoCr}$ alloy were produced to standardize the impressions. Metal cast number 1 simulated a full crown preparation of a superior premolar with a distance between the buccal-palatal edges of $6.5 \mathrm{~mm}$ and mesiodistally of $3.12 \mathrm{~mm}$. Cast number 2 was a metal cylinder that was $2 \mathrm{~mm}$ in diameter greater then Cast number 1 so there was a uniform clearance space to be filled with the soft impression material (Fig. 1).

\section{Individual Tray and Impressions}

To perform the impressions, sixty individual trays with a height of $35 \mathrm{~mm}$ and diameter of $20 \mathrm{~mm}$ were constructed from PVC tubes. After the cylinders were cut in the appropriate size, one of the edges was sealed with an acrylic resin circular plate and two perforations were done $5 \mathrm{~mm}$ below to provide retention of the heavy material. In the other edge two grooves were created to allow the withdrawal of the master cast after the impression was performed (Figs 2A and B).

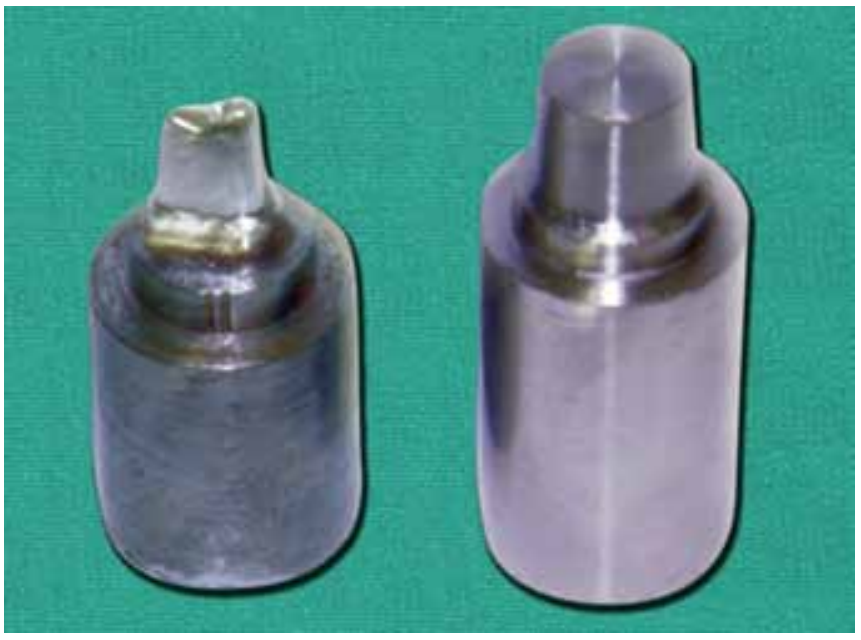

Fig. 1: Metal cast 1 and 2

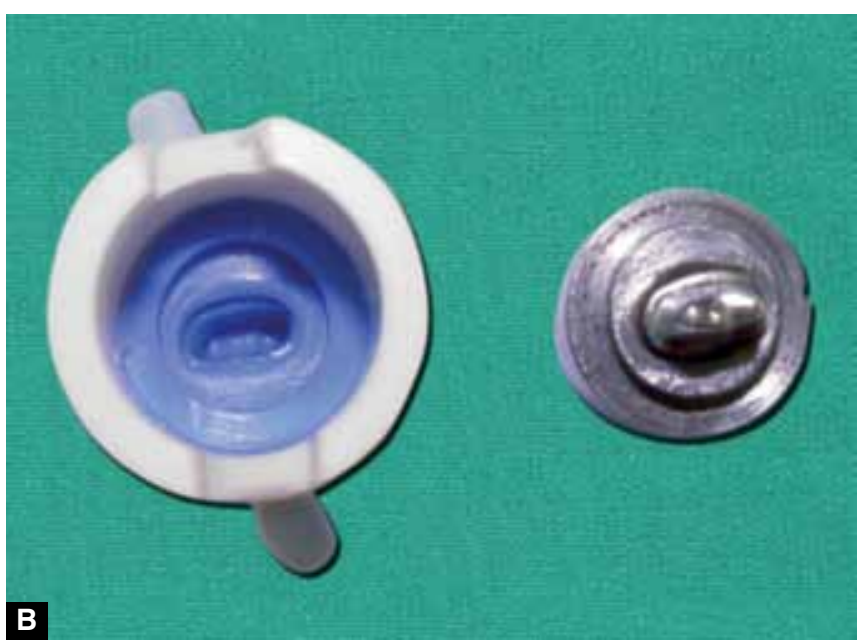

Figs 2A and B: (A) High-viscosity polyvinyl siloxane impression material was used in the first step with metal cast 2 of the impression to make a relief in the trays, (B) The ultra-light base impression material was inserted with a syringe in the tray for the final impression of the premolar metal cast 1 
The addition silicone impression was performed in a two-step technique, the material was used according to the manufacturer's instructions. At first the tray was filled with the high-viscosity polyvinyl siloxane impression material and the cast number 2 was inserted to create and standardize the uniform relief for the ultralight base impression material (Fig. 2A). After the polymerization of the heavy material the cast number 2 was removed, the ultra-light base impression material was injected inside the mold with an auto-mix syringe provided by the manufacturer and the cast number 1 was inserted. This cast was removed after the polymerization period (Fig. 2B) and the standard mold was obtained (Fig. 3), this procedure was performed 30 times to produce 30 addition silicone molds.

\section{Samples Production}

Polyether impressions were used according to the manufacturer's instructions in a one-step technique, since it is not necessary to create a clearance space. Cast number 1 was inserted after the complete filling of the individual tray with the polyether material. After the polymerization period the cast was removed and the mold was obtained, this procedure was repeated 30 times to produce 30 molds.

\section{Groups}

Molds were then divided in two groups according to each used impression material - addition silicone or hypochlorite. Then all specimens were randomized in three subgroups $(\mathrm{n}=10)$ : Group AC - addition silicone control (without disinfectant); Group APA - addition silicone $+0.2 \%$ peracetic acid; Group AH - addition silicone $+1 \%$ sodium hypochlorite; Group PC - polyether control (without disinfectant); Group PPA - polyether $+0.2 \%$ peracetic acid; Group $\mathrm{PH}$ - polyether $+1 \%$ sodium hypochlorite.

Initially all molds were washed in running tap water during 10 seconds and the disinfection protocol varied according to each group:

Groups AC and PC were not disinfected, samples were kept for 10 minutes in a solution of distilled water. Groups APA and PPA samples were submerged in a $0.12 \%$ peracetic acid solution for 10 minutes, to remove the disinfectant all molds were then washed with running tap water for
10 seconds. For groups $\mathrm{AH}$ and $\mathrm{PH}$ molds were submerged in $1 \%$ sodium hypochlorite for 10 minutes and to remove the disinfectant all samples were washed with running tap water for 10 seconds. After that all samples were sealed in a container for 50 minutes that had controlled temperature at $37^{\circ} \mathrm{C}$.

A single operator fabricated all casts with type IV gypsum according to the manufacturer's recommendations. After 45 minutes casts were removed from the molds and kept for 24 hours in a sealed container at controlled temperature at $37^{\circ} \mathrm{C}$.

\section{Measurements and Statistical Analysis}

After 24 hours the following measurements were performed with an optical comparator (Deltronic DV-114, Santa Ana, CA, USA) in the samples: cast height, cast base diameter, cast top diameter every evaluation site was measured three times and a mean value was obtained for each sample and group. A calibrated single operator conducted the analysis.

Mean values and standard deviations were calculated and were analyzed with the software Bioestat 5.0 (Mamirauá Institute, Amazonas, Brazil). Initially all obtained data underwent a normality test (Shapiro-Wilk test), followed by the two-way analysis of variance (ANOVA) to verify intra and inter groups differences. Significance level was adopted at $5 \%$ and all results were considered significant when $\mathrm{p} \leq 0.05$.

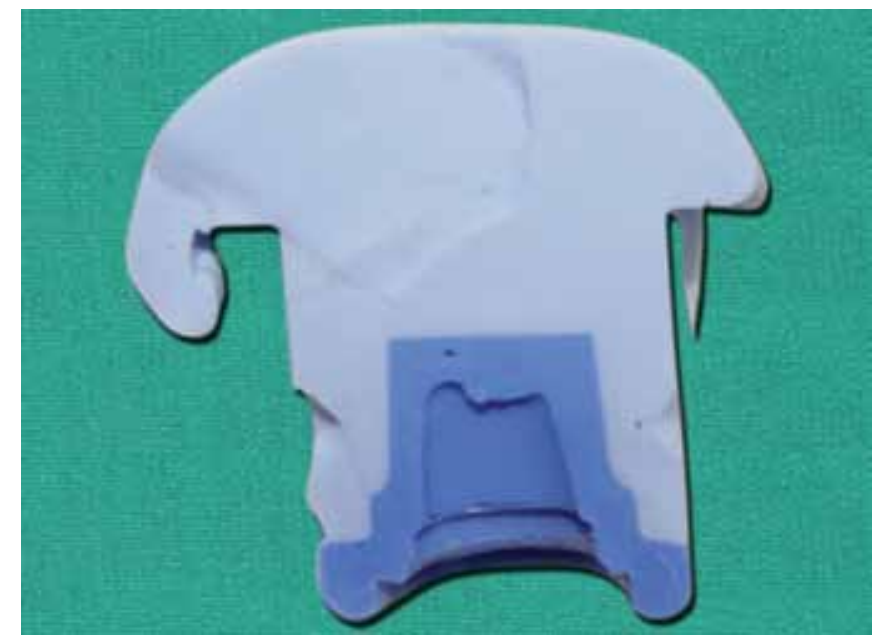

Fig. 3: Mold sagittal view: one of the master model (metal cast 2) was $2 \mathrm{~mm}$ larger than the other master model (metal cast 1) to provide a uniform relief for the two-step putty-wash impression technique (Aquasil - Dentsply)

\begin{tabular}{|c|c|c|c|c|c|}
\hline & & \multicolumn{3}{|c|}{ Disinfection method } & \multirow[t]{2}{*}{ Master model } \\
\hline & & $W D$ & $P$ & $H$ & \\
\hline \multirow[t]{2}{*}{ Addition Silicone (AS) } & Mean (DP) & $6.108( \pm 0.078) \mathrm{Aa}$ & $6.114( \pm 0.077) \mathrm{Aa}$ & $6.081( \pm 0.078) \mathrm{Aa}$ & $6.1( \pm 0.076)$ \\
\hline & $\mathrm{DM}$ & $0.13 \%$ & $0.22 \%$ & $0.32 \%$ & $0 \%$ \\
\hline \multirow[t]{2}{*}{ Polyether (P) } & Mean (DP) & $6.081( \pm 0.081) \mathrm{Aa}$ & $6.092( \pm 0.079) \mathrm{Aa}$ & $6.095( \pm 0.081) \mathrm{Aa}$ & $6.1( \pm 0.078)$ \\
\hline & DM & $0.14 \%$ & $0.14 \%$ & $0.10 \%$ & $0 \%$ \\
\hline
\end{tabular}




\section{RESULTS}

Mean values and standard deviation obtained for each group according to impression material, measured area and disinfection method are available in Table 2.

Distinct letters in uppercase horizontally and lowercase vertically differ from each group (ANOVA, $\mathrm{p}<0.05$ ).

There was not a significant statistical difference between groups that used addition silicone or polyether and the different methods of disinfection. Also, there was not a significant difference when comparing impression materials and the different used disinfectants.

\section{DISCUSSION}

Cross infection control is a relevant matter in dental practice nowadays since it may contaminate patients and different professionals of the involved areas. Several studies demonstrated that microorganisms are transmitted after impressions are taken regardless of the used material. ${ }^{1,4}$ The ADA recommends that molds should be disinfected by full immersion or spray with compatible products that will not interfere with material properties or promote alterations in the cast dimensions. ${ }^{5}$

Despite peracetic acid is underutilized in dentistry, it presents favorable characteristics to be indicated as a material of choice to disinfect dental impressions. It presents bactericidal, sporicidal and antifungal action even in the presence of organic matter and it is capable of removing or reducing the growth of intraoral biofilms. ${ }^{22,23}$ Also, its biocompatibility ${ }^{18}$ and efficacy in a short period of time ${ }^{20}$ makes this material more advantageous than other disinfectants, as much as glutaraldehyde.

During disinfection by immersion or spray chemical alterations may occur. However, these chemical interactions are not capable of interfere significantly in order to affect the final result of the impression. ${ }^{24-26}$ Water absorption of the materials is also altered, but despite the hydrophobic characteristic of the addition silicones and polyether hydrophilic properties, the dimensional changes of these materials after disinfection with hypochlorite or glutaraldehyde have not been considered significant. $3,7,10,24$

Disinfection by impression immersion has been proposed because the mold is completely in contact with the used product. Immersion for long periods were associated with significant dimensional alterations, to avoid this changes the time of disinfection should not exceed 30 minutes. ${ }^{27}$ In this study both $0.2 \%$ peracetic acid and $1 \%$ sodium hypochlorite were used for 10 minutes, minimizing the possibility of occurrence of dimensional alterations. The prepared molds did not present significant changes and showed minimum values of distortions, up to $0.5 \%$, which is comparable of the standards proposed by the ADA. ${ }^{5}$ Our results for the groups that used polyether differ from other studies where a higher distortion occurred after disinfection by immersion and the use of the disinfectant by spray and storage for 24 hours in a moisture free environment was suggested. ${ }^{25,28,29}$

Molds disinfection with peracetic acid did not interfere with the molds stability regardless of the impression material. It was demonstrated that this disinfectant was compatible with both materials showing similar results to hypochlorite, which is an effective method well described by literature. ${ }^{7,10,24}$ Also, due to the peracetic acid favorable characteristics it may be utilized, recommended and considered a safe disinfection agent.

Individual trays and metal master casts were used in order to reduce variables that could alter molds and casts dimensional stability. Impression material thickness utilized was uniform since the clearance space was standardized. This $2 \mathrm{~mm}$ space is a reliable and efficient technique to fabricate uniform relief. ${ }^{9,30}$ Also, impression was taken in a moisture free environment because the presence of water could interfere in the stability of the used materials.

Based on the obtained results, this study hypothesis can be proven. Molds can be disinfected with $0.2 \%$ peracetic acid prior to casting and this may be considered as a reliable disinfectant agent. Disinfection of the impression materials with the proposed agents did not present significant dimensional alterations. The minimum percentage of distortion obtained does not jeopardize the final result since it is usually compensated in the following steps in the fabrication of dental prosthesis.

Disinfection of molds with $1 \%$ sodium hypochlorite or $0.2 \%$ peracetic acid is recommended since it generates a reduction in the quantity of microorganisms and in the risk of cross-infection withouth compromising the final prosthesis'.

\section{CONCLUSION}

Based on the results obtained, both $0.2 \%$ peracetic acid and $1 \%$ sodium hypochlorite did not alter significantly the dimensional stability of the used impression materials. All casts presented clinically acceptable values of distortion. Peracetic acid can be considered a viable material to disinfect dental prosthesis molds.

\section{REFERENCES}

1. Al Jabrah O, Al Shumailan Y, Al Rashdan M. Antimicrobial effect of 4 disinfectants on alginate, polyether and polyvinyl 
siloxane impression materials. Int J Prosthodont 2007 MayJun;20(3):299-307.

2. Mehtar S, Shisana O, Mosala T, Dunbar R. Infection control practices in public dental care services: findings from one South African Province. J Hosp Infect 2007 May;66(1):65-70. Epub 2007 Apr 11.

3. Egusa H, Watamoto T, Abe K, Kobayashi M, Kaneda Y, Ashida $\mathrm{S}$, Matsumoto T, Yatani H. An analysis of the persistent presence of opportunistic pathogens on patient-derived dental impressions and gypsum casts. Int J Prosthodont 2008 Jan-Feb;21(1):62-68.

4. Haralur SB, Al-Dowah OS, Gana NS, Al-Hytham A. Effect of alginate chemical disinfection on bacterial count over gypsum cast. J Adv Prosthodont 2012, 4 May;4(2):84-88. Epub 2012 May 30.

5. ADA Council on Scientific Affairs and ADA Council on Dental Practice. Infection control recommendations for the dental office and the dental laboratory. J Am Dent Assoc 1996;127:672-680.

6. Kohn WG, Harte JA, Malvitz DM, Collins AS, Cleveland JL, Eklund KJ. Centers for Disease Control and Prevention. Guidelines for infection control in dental healthcare settings 2003. J Am Dent Assoc 2004 Jan;135(1):33-47.

7. Kotsiomiti E, Tzialla A, Hatjivasiliou K. Accuracy and stability of impression materials subjected to chemical disinfection-a literature review. J Oral Rehabil 2008 Apr;35(4):291-299. Review.

8. Chee WWL, Donovan TE. Polyvinyl siloxane impression materials: a review of properties and techniques. J Prosthet Dent 1992 Nov;68(5):728-732.

9. Nissan J, Laufer BZ, Brosh T, Assif D. Accuracy of three polyvinyl siloxane putty-wash impression techniques. J Prosthet Dent 2000 Feb;83(2):161-165.

10. Bock JJ, Fuhrmann RA, Setz J. The influence of different disinfectants on primary impression materials. Quintessence Int 2008 Mar;39(3):e93-98.

11. Semensato AP, Crosariol SK, Marchini L. Evaluation of the antimicrobial activity and dimensional alterations of alginate impression disinfectants. Eur J Prosthodont Restor Dent 2009 Sep;17(3):121-125.

12. Al-Omari WM, Glyn Jones JC, Wood DJ. The effect of disinfecting alginate and addition cured silicone rubber impression materials on the physical properties of impression and resultant casts. Eur J Prosthodont Rest Dent 1998 Sep;6(3): 103-110.

13. Shambhu HS, Gujjari AK. A study on the effect on surface detail reproduction of alginate impressions disinfected with sodium hypochlorite and ultraviolet light: an in vitro study. Journal of Indian Prosthodontic Society 2010 Mar;10:41-47.

14. Abdelaziz KM, Hassan AM, Hodges JS. Reproducibility of sterilized rubber impressions. Braz Dent J 2004;15(3):209-213. Epub 2005 Mar 18.

15. Giammanco GM, Melilli D, Rallo A, Pecorella S, Mammina C, Pizzo G. Resistance to disinfection of a polymicrobial association contaminating the surface of elastomeric dental impressions. New Microbiol 2009 Apr;32(2):167-172.

16. Hernandez A, Martro E, Matas L, Ausina V. In-use evaluation of Perasafe compared with cidex in fibreoptic bronchoscope disinfection. Journal of Hospital Infection 2003 May;54(1): 46-51.
17. Vizcaino-Alcaide MJ, Herruzo-Cabrera R, Fernandez-Aceñero MJ. Comparison of the disinfectant efficacy of Perasafe and $2 \%$ glutaraldehyde in in vitro tests. Journal of Hospital Infection . 2003 Feb;53(2):124-128.

18. Stampi S, De Luca G, Onorato M, Ambrogiani E, Zanetti F. Peracetic acid as an alternative wastewater disinfectant to chlorine dioxide. J Appl Microbiol 2002;93(5):725-731.

19. Ceretta R, Paula MM, Angioletto E, Méier MM, Mitellstädt FG, Pich CT, Junior SA, Angioletto E. Evaluation of the effectiveness of peracetic acid in the sterilization of dental equipment. Indian J Med Microbiol 2008 Apr-Jun;26(2):117-122.

20. Loukili NH, Granbastien B, Faure K, Guery B, Beaucaire G. Effect of different stabilized preparations of peracetic acid on biofilm. J Hosp Infect 2006 May;63(1):70-72. Epub 2006 Mar 15.

21. Ghahramanloo A, Sadeghian A, Sohrabi K, Bidi A. A microbiologic investigation following the disinfection of irreversible hydrocolloid materials using the spray method. J Calif Dent Assoc 2009 Jul;37(7):471-477.

22. Chassot AL, Poisl MI, Samuel SM. In vivo and in vitro evaluation of the efficacy of a peracetic acid-based disinfectant for decontamination of acrylic resins. Braz Dent J 2006;17(2): 117-121.

23. De Deus G, Souza EM, Marins JR, Reis C, Paciornik S, Zehnder M. Smear layer dissolution by peracetic acid of low concentration. Int Endod J 2011 Jun;44(6):485-490. doi: 10.1111/j.1365-2591.2010.01847.x. Epub 2011 Jan 24.

24. Turhan Bal B, Yilmaz H, Aydin C, Al FD, Sultan N. Efficacy of various disinfecting agents on the reduction of bacteria from the surface of silicone and polyether impression materials. Eur J Prosthodont Restor Dent 2007 Dec;15(4):177-182.

25. Lepe X, Johnson GH. Accuracy of polyether and addition silicone after long-term immersion disinfection. J Prosthet Dent 1997 Sep; 78(3):245-249.

26. Langenwalter EM, Aquilino SA, Turner KA. The dimensional stability of elastomeric impression materials following disinfection. J Prosthet Dent 1990 Mar;63(3):270-276.

27. Drennon DG, Johnson GH, Powell GL. The accuracy and efficacy of disinfection by spray atomization on elastomeric impressions. J Prosthet Dent 1989 Oct;62(4):468-475.

28. Peutzfeldt A, Asmussen E. Effect of disinfecting solutions on accuracy of alginate and elastomeric impressions. Scand J Dent Res 1989 Oct;97(5):470-475.

29. Rios MP, Morgano SM, Stein RS, Rose L. Effects of chemical disinfectant solutions on the stability and accuracy of the dental impression complex. J Prosthet Dent 1996 Oct;76(4):356-362.

30. Queiroz DA, Cunha LG, Duarte JLP, Neves ACC, da SilvaConcílio LR. Influence of the casting material on the dimensional accuracy of dental dies. Braz oral res [Internet]. 2011 Aug [cited 2012 Nov 12]; 25(4):357-361. Available at: http:// www.scielo.br/scielo.php?script=sci_arttext\&pid=S1806$83242011000400013 \& \operatorname{lng}=$ en.

\section{ABOUT THE AUTHORS}

\section{Daher Antonio Queiroz}

Professor, Department of Dentistry, University of Vila Velha, Vila Velha, Espírito Santo, Brazil 
Influence of Disinfection with Peracetic Acid and Hypochlorite in Dimensional Alterations of Casts obtained

\section{Marcelo Massaroni Peçanha}

Professor, Department of Prosthodontics, University Federal of Espirito Santo Vitória, Espírito Santo, Brazil

\section{Ana Christina Claro Neves}

Professor, Department of Prosthodontics, University of Taubaté Taubaté, São Paulo, Brazil

\section{Fausto Frizzera}

Full Professor, College of Dentistry at FAESA, Vitória, Brazil

\section{Mateus Rodrigues Tonetto}

Professor, Faculty of Dentistry, University of Cuiabá, Cuiabá, Brazil Laís Regiane da Silva Concílio (Corresponding Author) Professor, Department of Prosthesis, University of Taubaté, Taubaté São Paulo, Brazil

Correspondence Address: Rua Expedicionário Ernesto Pereira 110. Centro, Taubaté, São Paulo, Brazil-12020 270, Phone: +5512 36254149, e-mail: regiane1@yahoo.com 